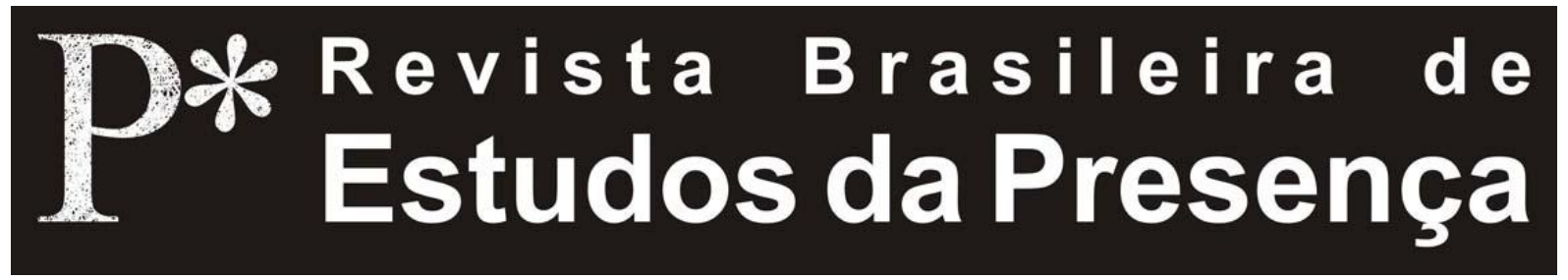

\title{
Pausa, Presença, Público: da Dança- Teatro à Performance-Oficina
}

\author{
Ciane Fernandes \\ Universidade Federal da Bahia - UFBA
}

\begin{abstract}
RESUMO - Pausa, Presença, Público: da Dança-Teatro à Performance-Oficina - $\mathrm{O}$ texto discute a tendência à paragem ou pausa dinâmica na cena contemporânea como uma busca por sintonia somática, numa atitude de contracultura e transformação. Em meio ao império do signo e do simulacro, a paragem ativa o fluxo interno $\mathrm{e}$ as conexões coletivas rumo à presença $\mathrm{e}$ inte(g)ração criativa com o meio. A partir de uma revisão histórica, de um debate teórico (Foster, Lacan, Ferál, Da Costa) e exemplos das artes cênicas, visuais, música e eventos da vida contemporânea - como catástrofes naturais e seu desdobramento midiático -, buscamos trazer uma reflexão acerca das prioridades e do papel do artista-pesquisador na contemporaneidade.

Palavras-chave: Pausa Dinâmica. Presença. Relação ArtistaEspectador. Performance. Sintonia Somática.
\end{abstract}

\begin{abstract}
Pause, Presence, Public: from Dance Theater to Workshop Performance - The text discusses the tendency to stillness or dynamic pause in the contemporary scene, as a search for somatic attunement, in an attitude of counter-culture and transformation. In the middle of an empire of signs and simulacra, stillness activates inner flow and collective connections towards presence and creative interaction/integration with the environment. From a historical review, through a theoretical debate (Foster, Lacan, Ferál, Da Costa), till examples of performing arts, visual arts, music, and contemporary life events - such as natural catastrophes and their media repercussions -, we intend to bring up an afterthought about the priorities and the role of the artistresearcher in contemporary times.
\end{abstract}

Ciane Ferandes, Pausa, Presença, Público: da Dança-Teatro à Performance-Oficina

R.bras.est.pres., Porto Alegre, v.1, n.1, p. 77-106, jan./jun., 2011.

Disponível em http://www.seer.ufrgs.br/presenca 
Keywords: Dynamic Pause. Presence. Artist-Spectator Relationship. Performance. Somatic Attunement.

RÉSUMÉ - La Puase, La Présence, Le Public: de la DanseThéâtre à la Performance-Atelier - Le texte débat la tendence à l'arrêt ou à la pause dynamique dans la scène contemporaine comme une recherche pour la syntonie somatique, dans une attitude de contre-culture et transformation. Au milieu de l'empire du signe et du simulacre, l'arrêt active le flux interne et les connexions collectives vers la présence et l'integration créative avec l'environnement. A partir d'un examen historique, d'un débat théorique (Foster, Lacan, Ferál, Da Costa) et des exemples des arts du spectacle, visuels, de la musique et des évennements de la vie contemporaine - comme des catastrophes naturelles et leur déploiement médiatique - nous cherchons à apporter une réflexion sur les priorités et le rôle de l'artiste-chercheur à l'époque contemporaine.

Mots-clés: Pause Dynamique. Présence. Rapport ArtisteSpectateur. Performance. Syntonie Somatique.

Todos os rios deságuam no oceano, mas o oceano não transborda, e em suas profundezas reina imperturbável tranquilidade - assim é o homem iluminado pelo conhecimento de si mesmo: de todas as partes o invadem as impressões dos sentidos - e submergem todas no seu Eu imóvel e imperturbável.

Bhagavad Gita

\section{Depois do Fim: em busca de uma realidade extrema}

Em 11 de março de 2011, a costa nordeste do Japão foi cenário de uma catástrofe avassaladora, resultado do terremoto de magnitude 8.9 na escala Richter. As imagens destruidoras do tsunami, com ondas de até dez metros de altura, invadiram os meios de comunicação de todo o mundo durante semanas. A repetição destas imagens chocantes nos ambientes mais diversos e íntimos do nosso cotidiano funciona como uma violenta pop art contemporânea, que nos tira do conforto e paralisa de terror. Como afirmou Siebens (2000, p. 225), a "nova arte" é aquela que extrapola a representação e é real: "[...] a nova arte é algo que acontece conosco [...]. O New York Times, o Newsweek, Time, e a CNN são os museus da nova arte".

Ciane Ferandes, Pausa, Presença, Público: da Dança-Teatro à Performance-Oficina

R.bras.est.pres., Porto Alegre, v.1, n.1, p. 77-106, jan./jun., 2011.

Disponível em http://www.seer.ufrgs.br/presenca 
A obra de arte midiática e violenta é como as cenas de acidentes automobilísticos expostas exaustivamente por Andy Warhol: "As repetições de Warhol não apenas reproduzem efeitos traumáticos; elas também o produzem" (Foster, 1996, p. 132). Como em tantos outros casos, a mídia espetacularizou a catástrofe, reproduzindo o momento traumático e produzindo um impacto sinestésico real. No entanto, diferentemente da neo avant-garde do final do século $\mathrm{XX}$, analisada por Foster (1996), esta espetacularização midiática gera o choque e a paralisia, e não o encontro com o Real. O tuché lacaniano de encontro com o Real atravessa o sintoma da fragmentação e, através do vazio, rompe com a repetição autômata (Wiederholung).

Portanto, a tendência da cena contemporânea à pausa ou paragem (Lepecki, 2005) deve ser abordada com cautela. A ausência de movimento pode ser vista em momentos de congelamento pós-traumático (Levine, 1993), em ciclos cotidianos de repouso e atividade que variam de cultura para cultura (Bastide, 1983), no preparo e no fechamento de uma frase de movimento ou de uma ação ou na transição entre elas, como um momento de fôlego, ou em técnicas, métodos e (não-)atos (ou Still Acts, Lepecki, 2005) criados especificamente com o intuito de transformar a percepção e atitude.

Todas estas pausas são de importância fundamental na cena contemporânea, e se atravessam nas diferentes variações de fluxo, como por exemplo, recostando lânguida e passivamente em algum objeto antes de dar um salto ou parando com o corpo firme e ereto diante do público. A inserção de momentos de congelamento traumático também é bem-vinda, e abre espaço para lidar com "[...] o sepultado, o descartado e o esquecido" (Buck-Morss apud Lepecki, 2005, p. 15), permitindo a reativação do fluxo e das qualidades dinâmicas (Fernandes, 2010).

Em 18 de março de 2011, a mídia transmitiu imagens de silêncio e pausa de todo o mundo, em homenagem às vítimas da tragédia japonesa. Mas um minuto foi muito pouco; logo substituído por outras manchetes bem mais ativas. Mais importante do que categorizar pausas, é dar-lhes espaço e deixarmos que 
assumam suas potencialidades. Assim, estes momentos deixam de ser intervalares e secundários à ação central, e passam a ser o elemento-eixo da cena, abrindo possibilidades criativas e de mudança de percepção rumo a uma "sintonia somática" (Nagamoto, 1992, p. 198).

\section{Entre Modernismo e Contemporaneidade: paradoxo, simultaneidade e transgressão}

Segundo Andre Lepecki (2005), o modernismo na dança desfez a oposição entre dança e paragem (stillness), estabelecida pelo balé romântico e pelo teatro de marionete de Heinrich Kleist (1810 apud Lepecki, 2005). A partir de coreógrafos como Isadora Duncan e Nijinski, a paragem passou a ser considerada como fonte repleta de movimento. Desta forma, a tendência à paragem na dança contemporânea resiste ao clichê do dançarino como ser em movimento e confirma seu parentesco com a performance art - arte da presença $\mathrm{e}$ da irreproducibilidade por excelência: "[...] engajar-se no parado significa [...] engajar-se em novas experiências da percepção de sua própria presença" (Lepecki, 2005, p. $14)$.

A paragem questiona a reprodução de movimentos aprendidos em anos de treinamento técnico, resistindo ao movimento mecânico, compulsivo e em série, como gestos pré-fabricados repetidos e combinados num tempo produtivo a ser preenchido exaustivamente. A busca da dança moderna por uma expressão pessoal e única instaura uma contradição com o momento histórico, pois floresce com sua força vital e originalidade em meio ao crescimento da industrialização, da produção em série, da reprodução padronizada e em massa da cultura pop.

Paralelo àquela organicidade da dança moderna do início do século XX, vimos florescer o corpo abstrato e non-sense de Hugo Ball (1916) e Tristan Tzara (1921) no Cabaré Voltaire, Oskar Schlemmer (1926) na Bauhaus, o Ballets Russes (1912-1921), e o Swedish Ballet (1924), liberando o gesto da ilustração e comunicação de um significado, e investindo na criatividade do inconsciente, juntamente com os surrealistas. Em busca de algo real e absoluto, Dada associou a ênfase emocional e impulsiva, centrada no indivíduo em conexão com a natureza, 
presente no Expressionismo (alemão), ao otimismo mecânico, formalista e pró-guerra do Futurismo (italiano). Isto resultou numa combinação contraditória e explosiva, intrinsecamente conflitante, uma atitude limítrofe simultaneamente contra a lógica e o sentimentalismo, uma revolução internacional de destruição e criação radicais.

Curiosamente, é em Zurique - centro pacífico e em repouso, no meio de uma Europa em plena guerra -, que brota um dos mais importantes movimentos da história das artes cênicas. No entanto, este período é pouco reverenciado, com exceção de sua mais recente ênfase na história da performance art (Goldberg, 1988) e livros específicos sobre o tema (Gordon, 1987). Inclusive, “[...] críticos e historiadores de teatro têm pulado de novo e novamente de Jarry para Artaud" (Melzer, 1994, p. xiii), negligenciando um período fundamental para a compreensão da cena contemporânea:

Há dificilmente uma "inovação" teatral realizada ao nosso público contemporâneo pelos teatros ambientais e psico-físicos, o acontecimento e o evento, que não tenha sido explorado antes de 1924 por Tzara, seus companheiros e discípulos. $\mathrm{O}$ nível da fantasia iconográfica das peças e performances dada, a qualidade plástica da encenação, as inovações em figurino e som, o fluxo de energia entre performer e audiência, não foram igualados no teatro contemporâneo até os anos de 1960. A ênfase no processo e espontaneidade no ato criativo liberava um grupo de energias que explodiu o mundo da performance numa ampla abertura (Melzer, 1994, p. xiv).

Vassily Kandinsky foi um dos pioneiros do abstracionismo, tendo influenciado Hugo Ball, além de ser também um admirador de Isadora Duncan em sua busca pelo movimento essencial. Kandinsky o encontrou no som musical, no som psicofísico do público e dos objetos, e no tom das cores - todos compreendidos como movimento. Suas composições para o palco reduziam cada ato à sua essência, integrando espaços vazios de tempo. Como escreveu a Schoenberg em 1911: "Sempre acho vantajoso em cada trabalho deixar um espaço vazio; tem a ver com não impor. Você não acha que nisso 
descansa uma lei eterna - mas é uma lei para amanhã" (Kandinsky apud Melzer, 1994, p. 17).

Além da ênfase na abstração e na liberdade de criação, outra estratégia de ruptura, presente principalmente nas artes visuais, foi $\mathrm{o}$ enfoque no "mínimo irredutível" - uma simplicidade radical, oposta à espetacularização, proposta por artistas como Kasemir Maliévitch e Marcel Duchamp (Paiva, 2010, p. 71). Este desnudamento, por mais abstrato e formal que seja, de fato nos aproxima do mundo das coisas. Veremos esta tendência renascer nos anos sessenta e setenta, tanto na dança pós-moderna norte-americana quanto na performance art, no famoso menos é mais da arquitetura (Ludwig Mies van der Rohe) e na paragem da dança contemporânea.

"O que o pintor Kandinsky denominara composição e o músico Schoenberg harmonia, Laban chamou de coreologia" (Berghaus, 1997, p. 94) ou ciência do movimento. A dança-teatro de Laban dialogava com as performances Dada no Cabaré Voltaire de Zurique (grande parte dos performers eram alunos de Laban), com os rituais de grupos alternativos junto à natureza (na dança-coral), com a educação e a pesquisa (ensino, escrita e notação). A influência de Kandinsky nos traços abstratos da notação criada por Laban é indiscutível. Como Kandinsky, Laban associou o impulso interior à abstração formal e interartística.

Enquanto no Expressionismo alemão a "[...] intensidade de sentimento e pathos de expressão valiam mais do que um refinado domínio da forma [...] a arte do movimento de Laban concentrava-se [...] na necessidade interior do artista de expressar os princípios objetivos subjacentes à experiência espiritual subjetiva" (Berghaus, 1997, p. 90 e p. 93). Como o Dada, a dança-teatro comunga com as duas tendências, numa estrutura intrinsecamente paradoxal, contrastante e radical que redefine a experiência da realidade. Esta natureza inclusiva e não-dual da dança-teatro a fará resistir e renascer em vários locais do mundo, influenciando e sendo influenciada pela cultura de várias localidades ao longo dos anos, inclusive pela dança pós-moderna norteamericana. 
A dança pós-moderna, cotidiana e funcional dos anos de 1960 e 1970, resistiu ao crescente tecnicismo e formalismo da tendência construtivista, bem como ao que passou a ser visto como emocionalismo e excesso de vigor da dança moderna, e que muitas vezes ganhou também uma forma padronizada a ser aprendida e imitada. Simplesmente caminhar em cena, realizar ações corriqueiras, carregar objetos, falar como se estivesse conversando com o vizinho, e usar trajes despojados passou a ser sinônimo de espontaneidade e inovação.

Também a paragem ressurgiu neste período, como irreverência, inovação e protesto. Dois exemplos são a composição musical 4'33" (1952), de John Cage, e o ato performático Waiting (1971), de Faith Wilding. Criada sob a influência do Zen Budismo, a partitura de 4'33" indica aos músicos que não toquem seus instrumentos durante os três movimentos da obra - o primeiro de trinta segundos, o segundo de dois minutos e vinte e três segundos, e o terceiro de um minuto e quarenta segundos. Em Waiting, Faith Wilding recita uma interminável lista de momentos de espera e expectativa na vida de uma mulher, desde o nascimento até a morte, enquanto permanece sentada passivamente numa cadeira de balanço em suave movimento.

Numa perspectiva paradoxalmente integrada, música é som e $(\mathrm{m})$ silêncio, dança é movimento $\mathrm{e}(\mathrm{m})$ pausa, performance é presença e $(\mathrm{m})$ ausência. Ao invés de oposições, dualidades e sucessivos instantes de um tempo linear, propomos uma abordagem somática, inclusiva e simultânea:

O espaçotempo é um conceito primário, ao invés do espaço ou do tempo separadamente ou adicionados. $\mathrm{O}$ bloco do espaçotempo pode ser fatiado em uma pilha de folhas curvas em um infinito número de maneiras diferentes. [...] Eventos em cada fatia são simultâneos mas observadores diferentes e em movimento, em cada uma delas, tem julgamentos diferentes... Esta configuração do bloco espaçotempo implica que o futuro já está aí. Em contraste, em outras ciências, o fluxo do tempo é associado ao desenrolar dos eventos, o aumento da informação, entropia e complexidade, e não há a 
sugestão de que o futuro está aí esperando (Barrow, 2001, p. 349-350).

Neste espaçotempo simultâneo, a alteridade reside no cerne da identidade e vice-versa, como já nos indicou Denise Jodelet (2009): "No cerne da experiência pessoal há sempre uma experiência de alteridade" (comunicação oral).

É neste contexto contemporâneo quântico que as diferentes tendências estéticas acima ganham espaçotempo de interação e transgressão, inicialmente como polifonias e multimeios, para o gradual renascimento daquilo que é mais fundamental, em um Retorno do Real (Foster, 1996).

Assim como a dança contemporânea vem reagindo ao clichê do movimento constante, usando a paragem como recuperação e proliferação de forças, as artes cênicas vêm resistindo ao massacre invasivo do mundo virtual através de uma estética de realidade extrema. No VI Congresso da ABRACE, UNESP, realizado em 2010, Josette Féral (2010) chamou a atenção para uma estética do choque, mostrando obras (inclusive documentários de genocídios) onde o corpo humano é dilacerado ou machucado de fato. Essa também foi a estratégia dos ativistas vienenses dos anos de 1960 (Günter Brus, Otto Mühl, Hermann Nitsch e Rudolf Schwarzkogler), entre outros no início dos anos de 1970 (como Gina Pane e Diamela Eltit), bem como sua contrapartida de exaltação dos sentidos através do prazer real, nas grandes orgias sensoriais daquela época, a exemplo de Meat Joy (1964), de Carolee Schneemann.

Além destes efeitos sensoriais, a cena contemporânea utiliza-se da repetição como meio de levar à exaustão e explosão do Simbólico. Outro artifício em busca da realidade é o uso irrestrito de espaços públicos impregnados de cotidiano e história. Assim, a intervenção urbana passou a ser um gênero frequente. Há também uma tendência a enfatizar questões e fatos políticos, e um retorno do papel social da arte, inclusive ecológico. Neste sentido, não apenas a relação com o meio ambiente ganha vazão, explorando o papel da arte como ativa no processo ecológico global, mas uma compreensão do ser humano como essencialmente 
ecológico, isto é, constituído bioquimicamente de elementos naturais e integrado dinamicamente com seu meio. A diferença e a multiplicidade surgem como elementos-chave, rompendo com noções de corpo ideal, exaltando o que cada um tem de especial, e explorando a combinação muitas vezes chocante de tipos e comportamentos.

A questão aqui - quer seja através da violência, do prazer, da espacialidade, do engajamento sociopolítico, da corporeidade, ou da sobreposição de todas estas forças e tendências em uma atitude de reflexão e concentração pré-ação (numa pausa muitas vezes mais carregada que qualquer ação) -, é uma busca por sobrevivência, um grito de alerta da cena, como um Dada contemporâneo, difuso e intenso em meio à guerra da mídia. Numa narrativa histórica espiralada (Heinrich Woelfflin apud Foster, 1996, p. 8), propostas e estratégias retornam modificadas, para desafiar e desestabilizar o senso comum e o conformismo. Assim, pouco a pouco, o enfoque da cena contemporânea deixa de ser o do simulacro, o da "[...] desmaterialização do real, o descentramento do sujeito, o desaparecimento do autor etc" (Da Costa, 2006, p. 276).

Minha preocupação não é distinguir dança moderna de pós-moderna, contemporânea etc. ou de distinguir entre gêneros das artes cênicas, como dança, teatro, dança-teatro, performance, intervenções, teatro físico, artes do corpo etc. A questão fundamental, e que parece atravessar a cena atual como um todo, reflete uma mudança radical de perspectiva, substituindo o vazio do simulacro (automaton) pela dinâmica da presença, acessada justamente através de um vazio criativo (tuché) - a paragem do performer - e da inclusão absoluta do espectador, a ponto de diluir tal categoria. A presença é a dinâmica entre experiência e consciência, impressão e expressão, substância e memória, o momentum entre esperar e agir. Através da pausa, do silêncio e da ausência, atravessamos a morte do Simbólico, ativando e intensificando o Real latente - o movimento, o som e a presença.

Duas obras de dança contemporânea bem distintas entre si e que ilustram o uso da paragem são Corpo 
Desconhecido (Curitiba, 2002), de Cinthia Kunifas, e Zero Degrees (Zero Graus, Londres, 2005), de/com Akram Khan e Sidi Larbi Cherkaoui.

Em Corpo Desconhecido, durante cerca de vinte minutos em um canto do palco, Kunifas opta por parar (ao invés de agir compulsivamente), prestar atenção no que já está acontecendo antes do movimento consciente acontecer (Foco pré-motor), inibir o impulso de se mover (Inibição), e redirecionar o foco (Direção) (Kunifas, 2008). O resultado é uma cena intensa que prende a atenção do espectador, implodindo a ausência de movimento até contaminar tudo com $K i$ (energia), já que uma das inspirações é o Método de Respiração de Nishino (Nishino, 1997) e o Yiquan (arte marcial que significa mente e intenção, criado na década de 1920 por Wang Xiangzhai). Através de sua paragem, Kunifas ativa uma energia supostamente invisível que está disponível a todo momento, como possibilidade ilimitada de criação:

No ponto zero de energia, quando tudo deveria estar em perfeito descanso, partículas ainda permanecem em uma vibração infinitesimal. Assim sendo, a vibração é o último limiar da persistência da realidade. O zero anuncia não o começo, nem o final, mas a moção vibratória microscópica constante em direção à modificação sem fim (Lepecki, 2000, p. 379).

Já a obra Zero Degrees é inspirada num fato real, e associa a herança intercultural de dois coreógrafos/dançarinos da atualidade, os dois europeus filhos de imigrantes (de Bangladesh e do Marrocos). A peça trata de uma experiência que Akram Khan teve ao viajar de trem de Bangladesh para a Índia, quando teve seu passaporte confiscado e presenciou a morte de outro passageiro, e foi influenciado por seu primo a não se envolver e, como todos os demais, não ajudar. Em meio a uma gama infinita de variações rítmicas, desde o frenético Kathak subliminar nos movimentos de dança contemporânea de Akran Khan ao suave canto marroquino de Cherkaoui sentado com um leve balanço, vemos surgir pausas reflexivas e "prenhas [...] em todos os lugares certos" (Kourlas, 2008, on-line). Para Akram Khan, Zero Degrees "[...] marca o centro em repouso 
através do qual passa o movimento, o momento da morte, transição" (Brown, 2005, on-line).

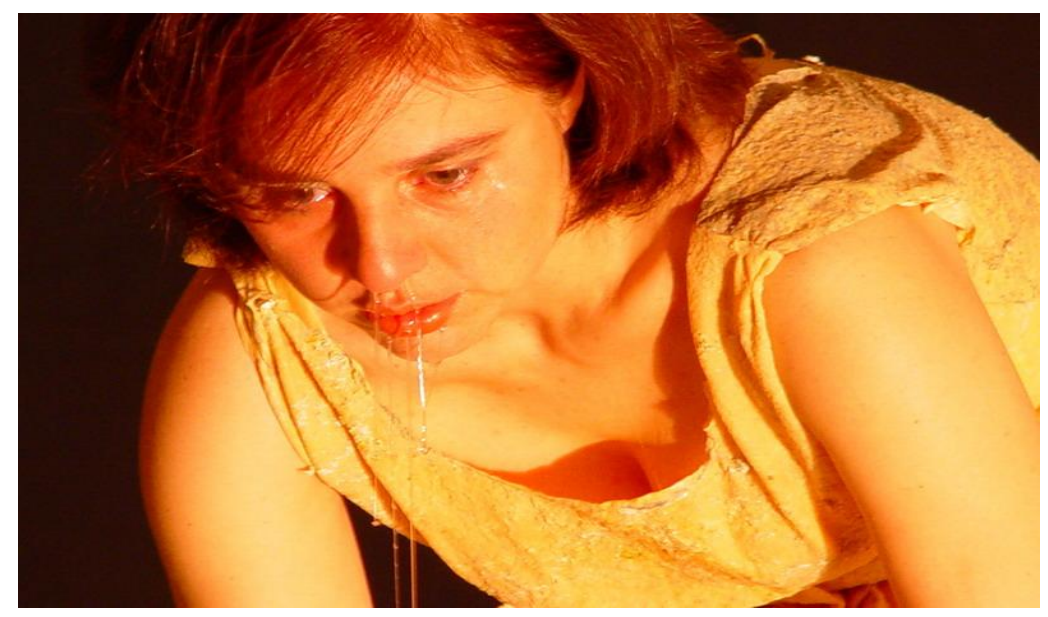

Figura 01. Cinthia Kunifas em Corpo Desconhecido (2002). Foto: Sérgio Ariel. Fonte: Kunifas, 2008.

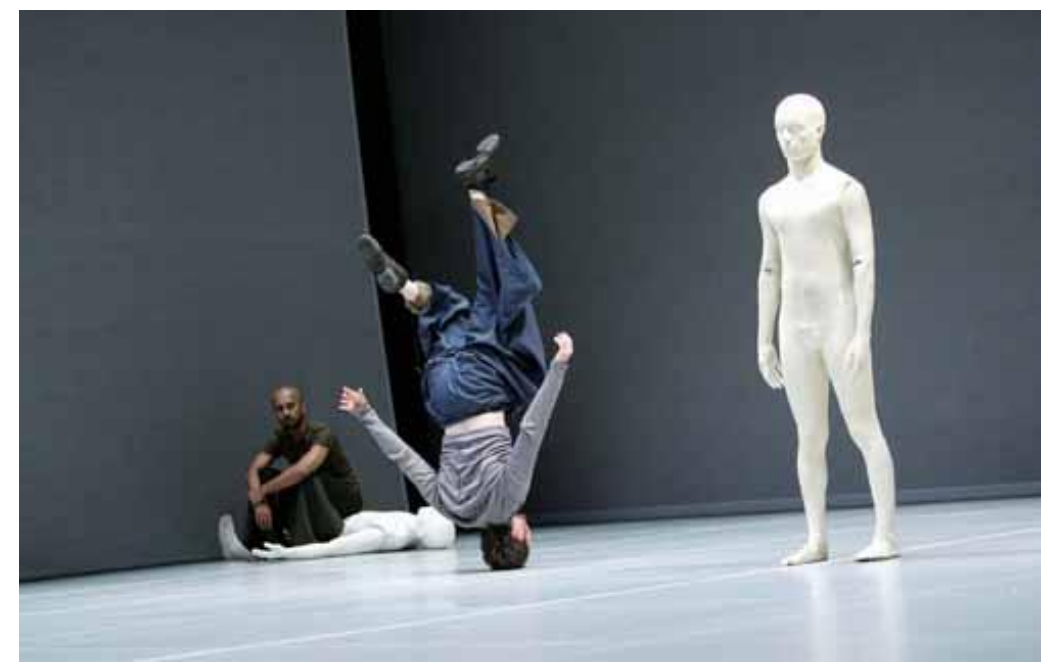

Figura 02. Akram Khan e Sidi Larbi Cherkaoui em Zero Degrees (2005). Fonte: Watts, 2005. Disponível em: <http://www.ballet.co.uk/magazines/yr_05/aug05/gw_rev_akram_k han_and_sidi_larbi_cherkaoui_0705.htm>. Acesso em: 12 jul. 2009.

\section{Antes do Começo: pausa dinâmica}

Após uma longa paragem, um pequeno movimento pode produzir um grande choque. Paragem é a coisa mais difícil de se fazer no palco. Dançarinos jovens não entendem isso de maneira alguma; eles só querem pular por toda parte (Park Myung-Sook apud Solomon; Solomon, 1997, p. 235).

Ciane Ferandes, Pausa, Presença, Público: da Dança-Teatro à Performance-Oficina R.bras.est.pres., Porto Alegre, v.1, n.1, p. 77-106, jan./jun., 2011. 
A paragem na cena contemporânea é uma saída possível para o excesso de informação midiática, a onipresença da cultura do portátil que virtualiza a sensação de espaço, o consumismo compulsivo, o bombardeio constante de estímulos, a crescente complexidade, velocidade e simultaneidade de eventos e demandas, associadas à desterritorialização do sujeito e à inconstância das relações. Isto tudo acrescido do aumento da população global, a eminente escassez de recursos naturais, a insuficiência na produção de alimentos, o aumento de contaminações e mutações genéticas incontroláveis (como o uso irrestrito de transgênicos e o surgimento das superbactérias).

A violência do cotidiano contemporâneo e a falta de perspectiva não passam desapercebidas e, a cada dia, aumentam os números de novas síndromes, doenças degenerativas e autoimunes, surtos, acidentes (inclusive desastres naturais e nucleares), depressões e intolerâncias, a exemplo das síndromes do pânico e do estresse póstraumático. A realidade atual já é traumática ao extremo. $\mathrm{O}$ retorno do real da neo-avant-garde não corresponde a uma reprodução deste contexto, naquela arte da mídia, mas sim numa des/resignificação radical do real, uma des/reorganização e relocalização espaçotemporal. Em meio a um contexto múltiplo, excessivo e avassalador, é justamente através do mínimo que se dá esse processo de ressignificação.

Em Rape Scene (Cena de Estupro, 1973), Ana Mendieta lida com um fato real que, ao contrário de outras modalidades de violência e catástrofes, tende a ser bem pouco divulgado pela mídia. O estupro e assassinato de uma estudante no campus da universidade de sua cidade a assustou de tal modo que ela reelaborou (não reproduziu) o evento em seu apartamento, deixando a porta entreaberta para a entrada sorrateira do público, tal qual agressores indesejados.

No espaço desarrumado, com pratos quebrados e sangue pelo chão, a artista está de costas para o público, desnuda da cintura para baixo, com sangue pelas pernas, o torso repuxado sobre uma mesa na qual tem seus punhos amarrados (Warr; Jones, 2000, p. 100). Sua 
inação é potente, arrebatadora e conflituosa. Ao mesmo tempo em que prende nossa atenção, ela nos repele; ao mesmo tempo em que nos identificamos com a vítima, fazemos o papel de invasores; ao mesmo tempo em que ela não consegue lidar com o fato real, ela o reconstrói.

Contraditória, sua paragem ativa memórias sinestésicas de cada um dos espectadores, muito além do fato real, em uma cadeia de ressignificação de medos, traumas e impressões. Através da paragem, Mendieta divide sua ansiedade com o público, nos tornando agentes e testemunhas de uma realidade coletiva subjetiva e desafiadora. Esta pausa não se assemelha em nada a assistir passiva e conformadamente a filmes de ação (de fato, agressão), por exemplo.

No contexto contemporâneo ameaçador, invasivo e incontrolável, a paragem - entendida como pausa dinâmica - restabelece a estabilidade do sujeito, possibilitando uma interação real baseada numa presença fluida. Estável é diferente de estático. É através da paragem que, paradoxalmente, o sujeito resiste ao movimento externo extremo e ativa o movimento interno intenso. Assim, a pausa ou paragem é intrinsecamente dinâmica, em fluxo.

A paragem é um caminho minimalista de aproximar-se do aqui e agora, por mais instável que ele seja, e justamente por isso. A relação entre minimalismo e presença nas artes visuais é explicada por Foster (1996, p. 43):

Minimalismo anuncia um novo interesse no corpo novamente, não na forma de uma imagem antropomórfica ou na sugestão de um espaço ilusionista de consciência, mas ao invés disso na presença dos seus objetos, unitários e simétricos como eles geralmente são [...] exatamente como pessoas.

Além do paradoxo da Mobilidade/Estabilidade, temos o do Interno/Externo, conceitos não-duais $\mathrm{e}$ compreendidos como reciprocamente geradores. É exatamente através da alteridade - desta não-ação diferente do ritmo do ambiente -, que ativamos nossa conexão fluida - sinestésica, energética e igualitária com o meio. Este, por sua vez, é transformado por aquela não-ação potente, arrebatadora e conflituosa.

Ciane Ferandes, Pausa, Presença, Público: da Dança-Teatro à Performance-Oficina

R.bras.est.pres., Porto Alegre, v.1, n.1, p. 77-106, jan./jun., 2011.

Disponível em http://www.seer.ufrgs.br/presenca 
A paragem permite a percepção e integração somática no espaçotempo, não como algo que se deve conquistar ou treinar, mas como uma possibilidade que já está aí esperando para ser vivida plenamente, como o futuro quântico (Barrow, 2001, p. 350). Rompe-se, assim, a cadeia da ação-reação, e do vazio "[...] escapam para a superfície social da consciência [...] o sepultado, o descartado e o esquecido tal como oxigênio vital" (BuckMorss apud Lepecki, 2005, p. 15), num evento imprevisível.

Como um menos que é mais, a não-ação desencadeia um processo de interiorização que ressignifica e instala a subjetividade como real, e não mais como uma abstração marginal à objetividade pragmática. Através do conhecimento somático, dissolvem-se oposições entre real e imaginário, objetivo e subjetivo, corpo e alma. A paragem ou pausa dinâmica é uma estratégia integradora que "[...] explode o mundo [do simulacro] numa ampla abertura [somática]", tal como o fez o Dada (Melzer, 1994, p. xiv). Transgride-se, assim, o uso da imagem (midiática) como reprodutora traumática, em prol de um imaginário intersticial (somático), onde a "ação postergada" (Nachtraeglichkeit) gera "[...] um tornar-se mais uma vez aberto" (Bhabha, 2005, p. 301).

Cientes do poder da pausa, muitas técnicas corporais utilizam-na como parte fundamental de seus ensinamentos. A pausa como exercício consciente pode ser encontrada em quase todas as técnicas de Educação Somática, como o Método Feldenkrais, os Fundamentos Bartenieff, a Ideokinesis, a Técnica Alexander, a Eutonia, entre outros (Bolsanello, 2010). As técnicas de Educação Somática tiveram grande inspiração nas técnicas corporais milenares advindas do oriente e cujo alicerce é uma visão integrada do ser humano - corpo, mente, emoções, espírito - e seu meio. Técnicas precursoras da integração corpo-mente e que têm a pausa como pilar são, por exemplo, o Ioga, o Tai Chi Chuan, o Qi Gong (Despeux, 1981; Ding, 1996), e os já citados Método de Respiração de Nishino e o Yiquan (Kunifas, 2008). As artes marciais, por sua vez, ilustram claramente a relação entre pausa como momento de produção e concentração 
de energia ou Chi (ou $K i$ ), e movimento intenso e consciente (com intenção clara) no espaço.

Mas as técnicas que mais exaltam a pausa pertencem a outro domínio - a do exercício para a mente. Parar ou aquietar-se fisicamente, dentro de uma disciplina específica de meditação, nos faz inicialmente perceber o movimento mental constante, tão invasivo e incontrolável como o mundo virtual e midiático, ou como o tempo produtivo e compulsivo. A observação da "[...] presença penetrante da impermanência da vida" é o primeiro passo para uma mudança de atitude rumo a uma sintonia somática (Nagamoto, 1992, p. 198).

Através da meditação, cria-se um campo magnético de onde emana o "mínimo irredutível" afetivo da pessoa: "[...] este campo somático mostra a presença qualitativa de um corpo pessoal particular" (Nagamoto, 1992, p. 205). Ou seja, através da paragem ativa-se a energia ou Expressividade do performer, aquelas variações de qualidades dinâmicas tão fundamentais para $o$ funcionamento da cena, integrando honestidade pessoal e engajamento estético.

\section{CorpoAbertoCorpoFechado: GEBO $\pi$ (Paisagens Internas)}

Teríamos que nos lembrar, porém, que bem possivelmente seja inevitável para essa arte - em que o real se insinua com tal força - manter-se, paradoxalmente, no campo do simbólico e do sistema artístico institucional (museus, instituições de apoio e patrocínio, circuitos de veiculação etc.) (Da Costa, 2006, p. 276).

Este foi exatamente o desafio da Mostra de Performance CorpoAbertoCorpoFechado, sob curadoria de José Mário Peixoto, que aconteceu na Galeria Cañizares da Escola de Belas Artes da Universidade Federal da Bahia (UFBA) de 16 a 20 de maio de 2011 (vide release e programação no Anexo I):

O objetivo do evento é reunir artistas performáticos e coletivos de performances urbanas em atuação na cidade de Salvador-Bahia e no Recôncavo Baiano para uma série de apresentações e debates sobre a transposição de propostas pensadas para o espaço urbano, as ruas, em direção ao 
espaço institucional, o museu, a galeria. Como os impedimentos e as regras inerentes à exposição no cubo branco modificam o formato de uma performance ou ação pensada originalmente para o espaço urbano? (Peixoto, 2011, s.p.).

A obra de dança-teatro-ritual intitulada $G E B O$ Runa da Parceria (2010) é um solo criado ao longo de três anos de processo criativo (Fernandes, 2010). A partir da apresentação no palco (versão de 14 minutos), a obra foi reconstruída em meio ambiente natural (floresta) em uma versão de uma hora, sem público, documentada em imagem digital. A versão coreografada havia sido montada numa estrutura aberta, a partir de princípios de movimento identificados e selecionados ao longo de uma hora de Movimento Autêntico filmado (Whitehouse, 2000). Já a versão prolongada na natureza recria movimentos a partir destes princípios selecionados, expandindo-os conforme o momento. Neste processo entre condensação cênica e expansão real, reverberam padrões criativos. Isto é, determinados estados de des/reorganização somática reaparecem de modos semelhantes, porém em contextos diferentes e dilatados ou concentrados em outros movimentos novos, ao longo de todo o processo.

Por exemplo, chutes com as pernas em posição deitada, na sessão de Movimento Autêntico três anos atrás, romperam grande congelamento traumático, mas não desenvolveram-se a ponto de provocar a mudança de decúbito. Já no processo de condensação para a coreografia, este movimento retornou em vários momentos, gerando um impulso para sentar e posteriormente levantar. No ambiente natural, após longa pausa dinâmica em contato com o solo repleto de folhas úmidas, estes movimentos ressurgiram sem uma intenção premeditada. Foi como se houvesse uma reconstrução da sessão de Movimento Autêntico, porém concentrada como em uma cena para o palco. Nesta reaparição dos chutes, surgiram deslocamentos como deslizamentos por todo o solo, o que não havia ocorrido até então em nenhum momento.

Ou seja, a repetição não intencional de um movimento, inicialmente selecionado, gera movimentos 
fora do padrão. Portanto, diferente de buscar algo novo numa eterna improvisação ou criar composições a partir de uma fonte e/ou técnica específica de movimento, tenho buscado identificar padrões criativos que, paradoxalmente, mudam ao se repetirem. É como aquela sensação de voltar a algum lugar vinte anos depois e reencontrar amigos com os quais se sente tão à vontade, e conversar sobre coisas recentes. Ou visitar um lugar pela primeira vez e encontrar ali, inesperadamente, um grande amigo de muitos anos atrás. Tudo mudou nestes anos, mas a conexão fluida entre as pessoas permanece e se renova.

Desde agosto de 2010, tenho expandido a proposta de $G E B O$ para um coletivo em meio ambiente, ao que chamei de GEBO $\pi$ (Paisagens Internas) (Fernandes, 2010). As performances do A-FETO Grupo de DançaTeatro da UFBA (GDT-UFBA) têm sido realizadas na área restrita do Parque Zoobotânico Getúlio Vargas, em Salvador, em sessões de Movimento Autêntico com maquiagem, figurino e filmagem digital. Esta última é compreendida como performance e, portanto, pretendemos usar as imagens sem edição. Não temos público, porém as sessões são abertas para novos participantes, que passam a integrar os duetos de Movimento Autêntico.

Neste método, o grupo divide-se em duplas, nas quais os papéis de observador e de realizador são revezados durante as três horas de atividade. $\mathrm{O}$ realizador move-se de olhos fechados, escutando e seguindo os impulsos de seu corpo, muitas vezes imprevisíveis ou mesmo estranhos a ele próprio. Durante a improvisação do realizador, o observador acompanha e protege $o$ colega, porém sem interrompê-lo nem julgá-lo. Após mover-se, o realizador e seu observador trocam ideias, desenhos, poesias etc., sobre a experiência. O processo então é repetido, mas com papéis revezados. Ao final da sessão, as duplas agrupam-se para trocar ideias ou para outras formas de expressão sobre as experiências.

Este método é como uma meditação em movimento, onde, a princípio, não precisamos fazer nada específico, exceto prestar atenção aos impulsos de movimentos, seguindo-os ou não, optando por seguir 
aquele impulso ou esperar um próximo. Trata-se de um exercício - tanto para o realizador quanto para $o$ observador - de intenção e clareza para ser movido e mover-se, sem compromisso com formas ou expectativas.

Quando recebemos o convite para a mostra CorpoAbertoCorpoFechado, buscamos reproduzir os desafios das sessões no meio ambiente, desta vez no espaço da galeria. Princípios fundamentais que geram este desafio são o da simultaneidade ou sobreposição de processo e produto, a erradicação da categoria espectador, e aquela estrutura coreográfica aberta, baseada em padrões criativos de movimento. Ainda, neste caso, tivemos padrões criativos de música, som e silêncio, editados durante a performance por um realizador/observador do GDT-UFBA (Felipe André Florentino).

A partir destes princípios dinâmicos, criamos o que chamamos de GEBO $\pi$ Performance-Oficina, com a participação de Ana de São José (Figura 03), Ciane Fernandes (Figura 10), Daiane Leal, Felipe Florentino, Frank Haendeler (Figura 05), Lenine Guevara, Morgana Gomes (Figura 06), Sol Tapia e a maioria do público presente. Em 19 de maio de 2011, de 19h30min as 20h, nas três salas da Galeria Cañizares, diferentes momentos do processo eram reproduzidos.

$\mathrm{Na}$ parede da sala de entrada, era projetado o vídeo-documentário de $G E B O$ solo versão expandida na natureza, de cerca de 50 minutos de duração, da autoria de Uirá Menezes. Este vídeo foi editado o mínimo possível (por João Rafael Neto), retirando-se apenas alguns poucos minutos ao longo da fita, criando um todo contínuo. Na sala de bate papo, vídeos do processo em grupo no Jardim Zoobotânico, sem nenhuma edição, eram exibidos no monitor. Na sala principal, um vídeo de imagens da natureza (o ambiente desejado e ausente) era projetado entre três paredes, como fractais em movimento - já que as imagens de rios, lagos, pedras, nuvens etc. era, muitas vezes, em close e tornava-se abstrata e (in)orgânica. Nos últimos minutos deste vídeo, a água em close transforma-se em minúsculas linhas abstratas em movimento, como numa "vibração infinitesimal" (Lepecki, 2000, p. 379). 
Enquanto isso, nas três salas, realizávamos a proposta da Performance-Oficina. Todas as pessoas ali presentes foram chamadas a participar, e a aceitação foi representativa. Como os integrantes do próprio GDTUFBA, o público dividiu-se em realizador e observador. Durante cerca de quinze minutos, uma das pessoas de cada dupla se moveu (ou não), sendo observada e cuidada pelo colega. Nos quinze minutos seguintes, invertemos os papéis.

A proposta criou uma situação bem interessante. Nos primeiros quinze minutos, por exemplo, eu observei Frank Händeler (Figura 05), do GDT-UFBA, bem como tive a oportunidade de testemunhar o movimento de outros integrantes do grupo e várias pessoas do público, todos juntos. Eu era espectadora daqueles que tinham ido até ali para me ver dançar, e eles se misturavam com alguns dos profissionais que foram até ali com esta função também. Em seguida, eu dancei em meio à outra metade do GDT e do público, e, portanto abri mão da minha posição de diretora externa. Algumas poucas pessoas optaram por serem observadoras durante os trinta minutos. Mas a maioria dissolveu fronteiras, inclusive de espaço, experimentando nos corredores, nas escadas, com a voz, entre imagens projetadas etc.

Os integrantes do GDT-UFBA dissolveram também fronteiras de tempo, reproduzindo padrões criativos presentes em outras sessões e obras anteriores, que retornaram entre novos movimentos, e desenvolveram-se conforme o impulso imprevisível do momento. Compreendendo a contemporaneidade como espaçotempo de possibilidades, nossa presença é dinâmica e nos torna "extemporâneos" (Nietzsche apud Quilici, 2010, p. 25):

O autêntico "filho" do seu tempo [...] perde a vinculação estritamente familiar com a época. Mantendo-se estrangeiro a ela, ele não se instala numa certa representação do "presente". Pode descobrir outros modos de relação com o tempo, pode ser atravessado por outras épocas e engendrar outros devires. O tempo abre-se para ele como uma questão (Quilici, 2010, p. 26).

A realização da proposta em outros eventos, provavelmente de modo diferenciado, promoverá a 
continuação desta proliferação criativa, fazendo com que também o público gradualmente identifique, reative e reconstrua padrões de mudança. Por exemplo, o integrante do GDT-UFBA e vídeo-maker João Rafael Neto, pretende trabalhar como VJ (DJ de imagens) numa composição genuína a partir de fragmentos de sessões do grupo e performances públicas (inclusive a que estiver acontecendo em tempo real). Outra proposta é realizar a performance-oficina com telepresença em dois ou mais lugares, simultaneamente, com realizadores e observadores mistos (do local e de lugares distintos).

A performance-oficina na Cañizares foi permeada pela dinâmica entre pausa e movimento, nem sempre associados respectivamente a observador e realizador. Muitas vezes, os realizadores ficavam parados, conectando-se com o momento de foco e dilatação internos. Por outro lado, várias vezes, os observadores atravessavam o espaço em gestos práticos e funcionais, tentando proteger seu companheiro/a, em meio a vários realizadores. Os movimentos destes eram muitas vezes imprevisíveis, casualmente semelhantes ou alternados. Estas combinações e contrastes, além das pausas e impulsos de ambos - observadores e realizadores - e da qualidade diferenciada entre eles (foco externo, foco interno), geraram uma composição altamente dinâmica. Bem, isto eu digo tanto como observadora quanto como realizadora, uma vez que obtive impressões das duas maneiras, o que torna essa análise visual e sinestésica.

A seguir, dez fotos da performance-oficina foram inseridas conforme a ordem de acontecimento em 19 maio 2011 (vide legenda geral das figuras 3 a 12 após esta última). Já o vídeo, editado por Artur Scovino, está disponível em: <http://www.youtube.com/watch?v=oniJoVwlCPY>. 

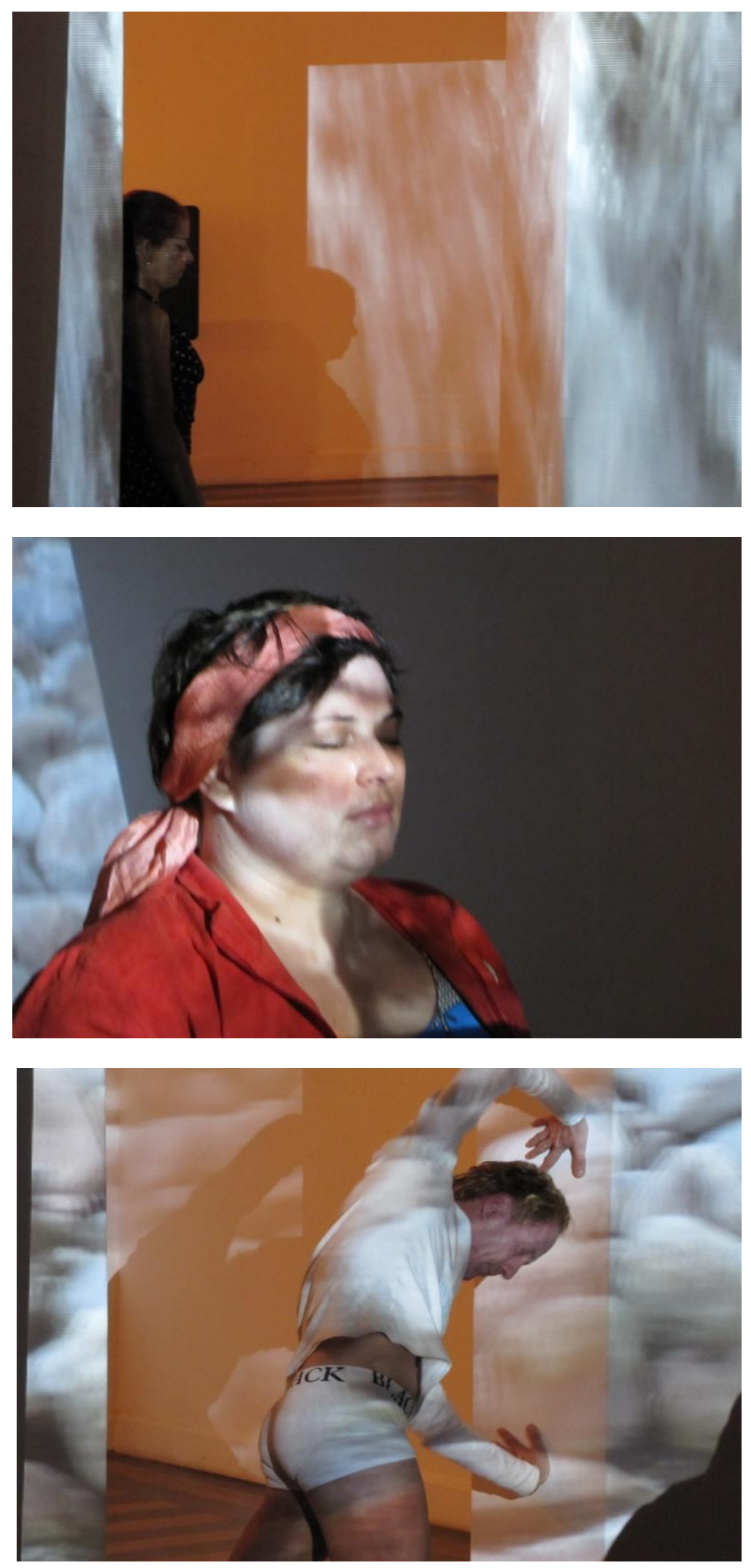

Ciane Ferandes, Pausa, Presença, Público: da Dança-Teatro à Performance-Oficina R.bras.est.pres., Porto Alegre, v.1, n.1, p. 77-106, jan./jun., 2011. 

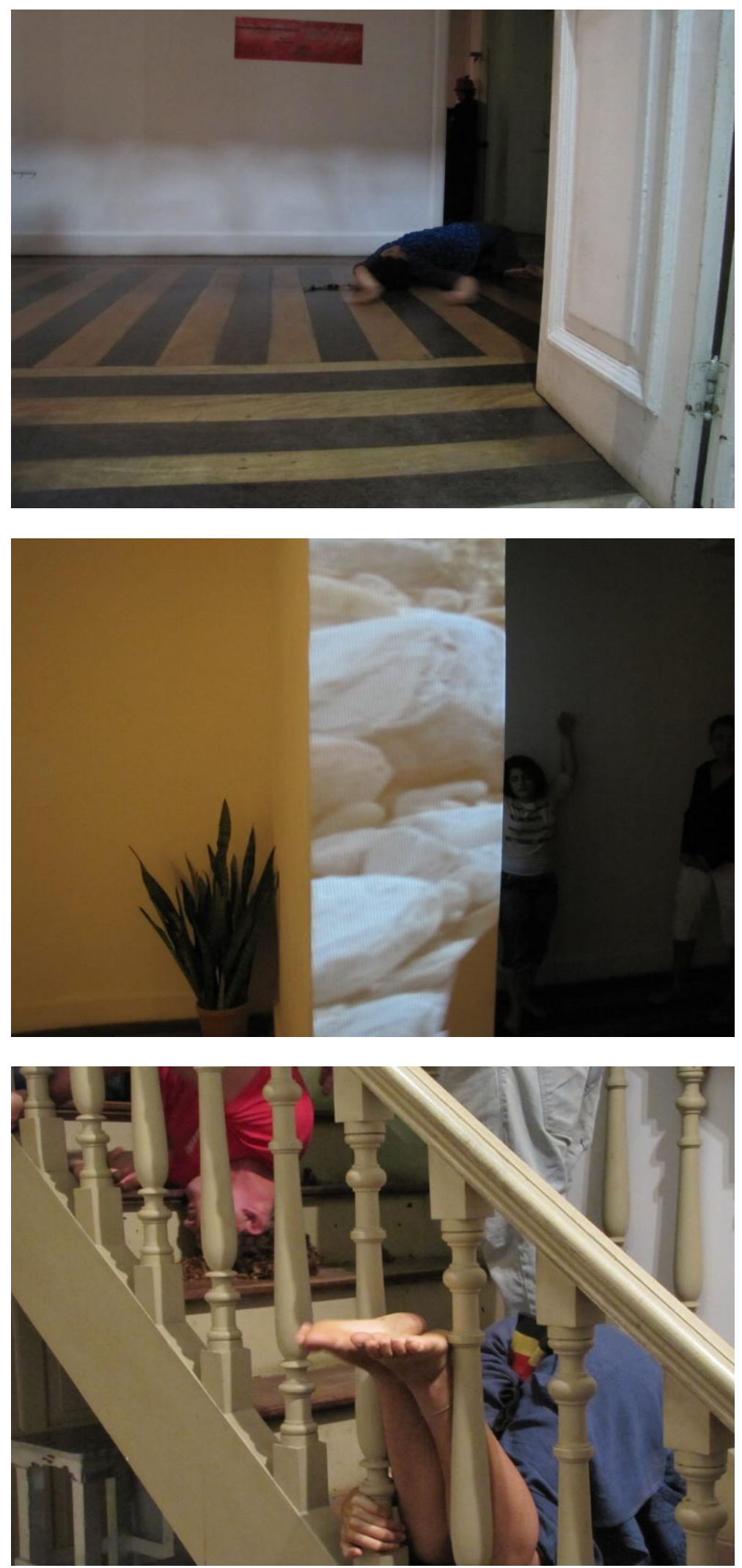

Ciane Ferandes, Pausa, Presença, Público: da Dança-Teatro à Performance-Oficina R.bras.est.pres., Porto Alegre, v.1, n.1, p. 77-106, jan./jun., 2011. 

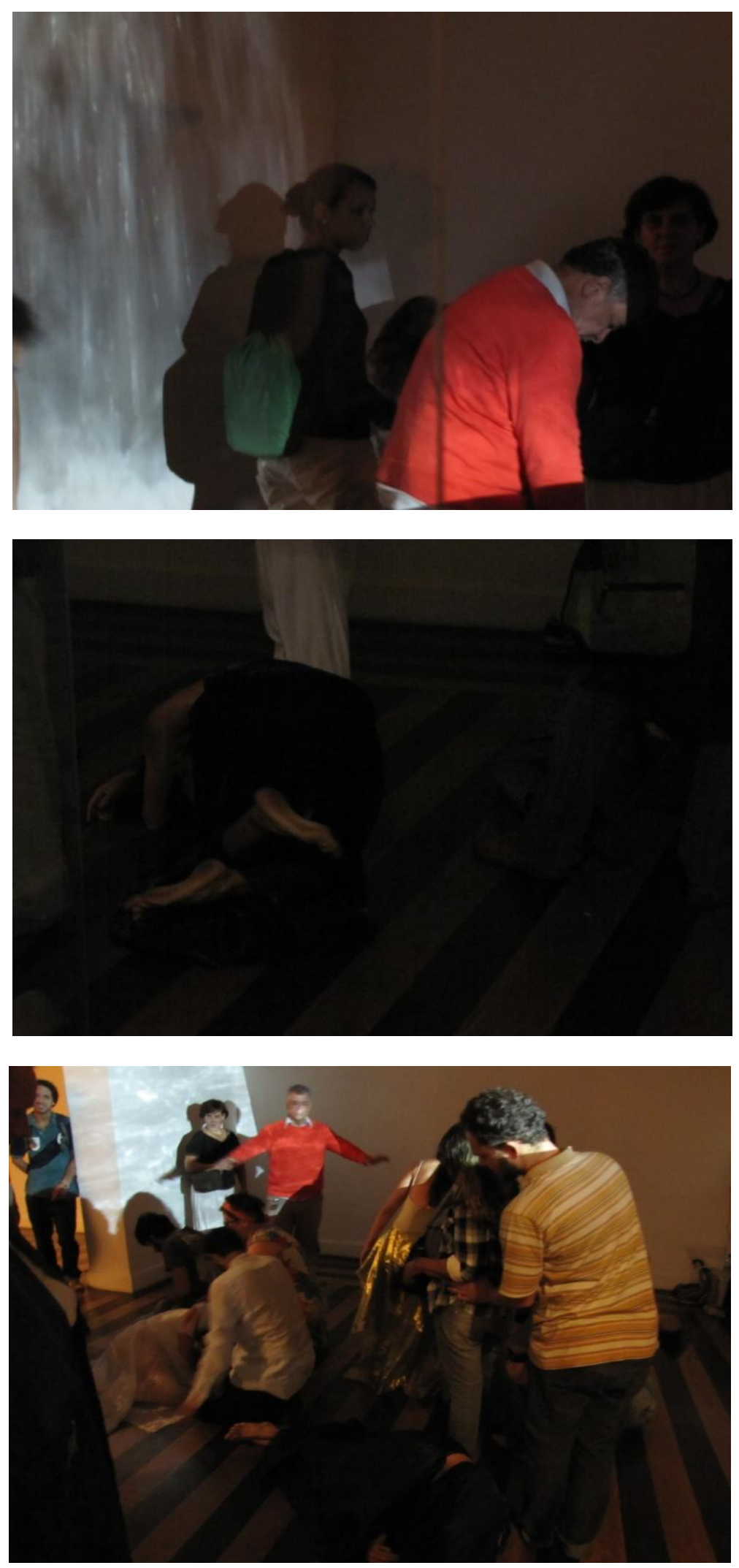

Ciane Ferandes, Pausa, Presença, Público: da Dança-Teatro à Performance-Oficina R.bras.est.pres., Porto Alegre, v.1, n.1, p. 77-106, jan./jun., 2011.

Disponível em http://www.seer.ufrgs.br/presenca 


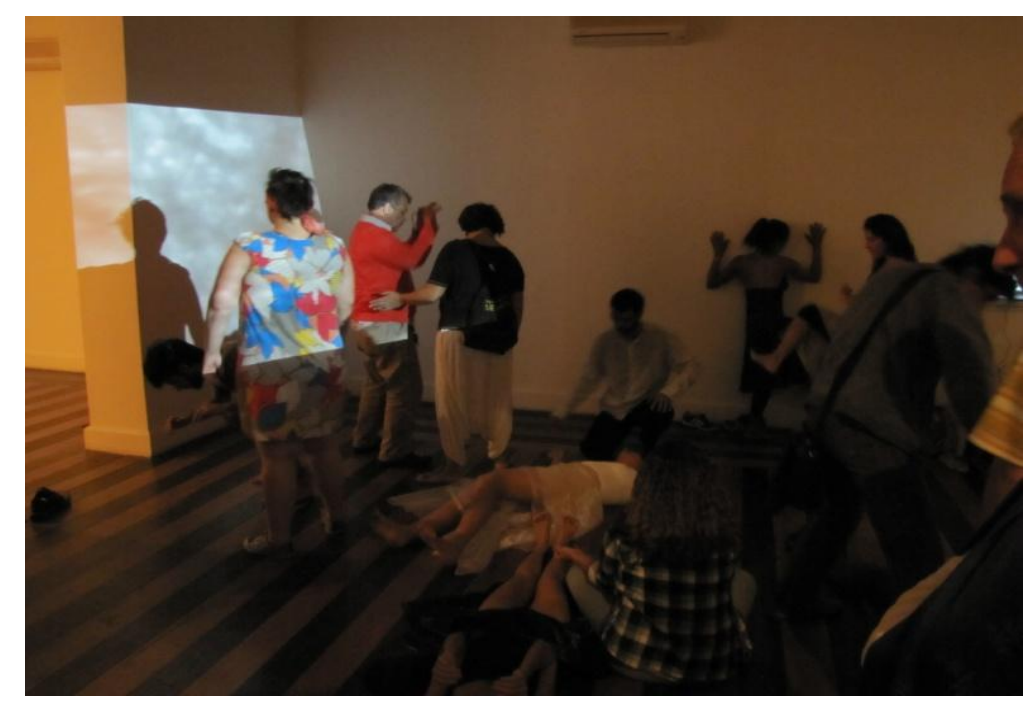

Figuras 03 a 12 - GEBO $\pi$ Performance-Oficina na Mostra CorpoAbertoCorpoFechado. Fotos de Arthur Scovino. A ordem destas 10 fotos segue a sequência dos eventos na performance.

\section{Defesa Fluida: uma proposta sensível para o espaçotempo acadêmico}

Em abril de 1995, entreguei minha tese de doutorado para leitura da banca na New York University. A defesa estava marcada para o final de maio, porém a colação de grau de todos os alunos daquela universidade acontecia em uma solenidade pública de grande porte, na praça Washington Square, somente uma vez ao ano, poucos dias antes da minha defesa. Como retornaria ao Brasil após a defesa, fui autorizada excepcionalmente a participar da cerimônia de colação de grau juntamente com os outros recém-doutores da Escola de Cultura, Educação e Desenvolvimento Humano, mesmo ainda não tendo passado pelo ritual da defesa.

No dia da solenidade pública, com a praça lotada de estudantes vestidos a caráter, com becas da universidade (tom roxo escuro) alugadas especialmente para a ocasião, percebi meu deslocamento. Cada turma comemorava ao ter seu nome chamado pelo reitor no microfone, jogando boinas para o alto, dando gritos etc. Ao chamarem a turma de doutores onde eu me inseria, a resposta foi praticamente inexistente. Era como se o diploma de doutorado fosse um atestado de óbito. 
Logo em seguida, de repente, começou um tumulto no meio da praça, e ao perguntar a um colega doutor do que se tratava, ele me explicou que era uma tradição tola dos graduados em interpretação teatral, de se jogarem na fonte do parque para selar a cerimônia. Não me recordo exatamente como, mas me lembro de estar, no minuto seguinte, em meio àquela fonte da juventude, com meu coração de estudante pré-doutor.

Comecei imediatamente a performar minha cena favorita de 1980 - Uma Peça de Pina Bausch (Fernandes, 2000, capa e p. 84) tendo casualmente a meu lado um calmo graduando de interpretação teatral, cinicamente carregando uma maleta acadêmica, um vaso de flores e um guarda-chuva aberto. Algum tempo depois, descobri que havíamos sido flagrados, em meio àquele intenso fluxo aquoso, pela amiga e correspondente do jornal português $O$ Público. A partir do registro documental que confirma a natureza fugaz da performance (Auslander, 2006), apenas então percebi o contraste entre eu e o desconhecido, de origem asiática, num claro diálogo entre Ebulição e Paragem ou Agitação e Quietude (Stir and Stillness, Laban, 1939, publicado 1984).

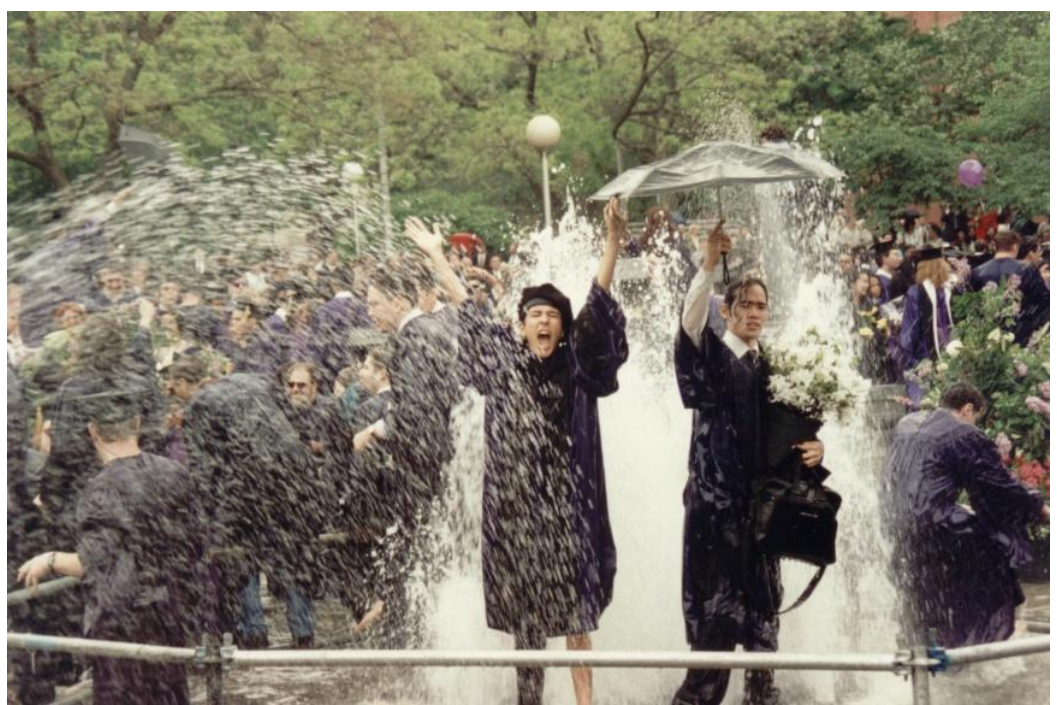

Figura 13. Ciane Fernandes em colação de grau de doutorado. Washington Square Park, 1995. Foto de Bárbara Reis. Fonte: arquivo da autora. 
Hoje, professora da Escola de Teatro da UFBA, acredito ser o momento de reavaliar as cerimônias estáticas da academia, em busca de uma coerência criativa e fluida. Um doutorado não pode mais ser o resultado de vinte e cinco anos de massacre corporal, consolidados em um ritual de congelamento generalizado. Você já tentou respirar fundo, suspirar ou se espreguiçar no meio de uma defesa de tese? Qualquer movimento, por mínimo que seja, parece proibido. É o momento do Grande Observador, do império do Simbólico, da Casa do Pai. Como proceder aquele retorno ao Real neste contexto engessado?

Uma opção - a meu ver revolucionária - foi proposta por Daniel Becker Denovaro, em sua defesa de tese intitulada Diálogos somáticos do movimento: o Método Pilates para a Prontidão Cênica. Na ocasião, o palco do teatro do Instituto Goethe de Salvador, onde se realizou a defesa, foi tomado por todos os tipos de objetos e móveis, criados por Isabela Moody Silveira, com a filosofia do Método Pilates.

Assim, durante as falas, a banca se exercitava ou se apoiava (muitas vezes em pausa dinâmica) nos objetos e móveis mais diferentes, ergonômicos e terapêuticos que já vi. Não apenas evitamos o cansaço e dores das horas de posição repetitiva, como também trabalhamos somaticamente durante aquelas horas, resolvendo dores localizadas existentes já antes da defesa. O público também foi convidado a interagir com o cenário, porém poucos o fizeram, provavelmente por falta de hábito. No entanto, o clima geral foi cativante, a arguição e discussão extremamente construtivas e dinâmicas. A pausa deixou de ser congelamento e controle para ser "um tornar-se mais uma vez aberto" (Bhabha, 2005, p. 301).

Através da criação artístico-acadêmica somática, podemos perceber criticamente o contexto contemporâneo, que impõe uma produtividade científica ideal, porém crescente e, contraditoriamente, autômata. Através da pausa dinâmica, artistas-pesquisadores reativam o movimento interno intenso - tanto como pessoas quanto como coletivo -, e retomam o fluxo entre criação e reflexão, vivência e análise, processo e produção, consciente e inconsciente, abrindo 
espaçostempos fundamentais e únicos de percepção e mudança para a humanidade, que vivencia um momento de crise, em todos os níveis.

\section{ANEXO I}

\section{CorpoAbertoCorpoFechado}

Mostra de Performance na Galeria Cañizares

Rua Araújo Pinho, 16-202. Canela. Salvador, Bahia, Brasil

Escola de Belas Artes - UFBA

De 16 a 20 de maio de 2011

Das 19h às 21h

www.corpoabertofechado.blogspot.com

http://www.youtube.com/watch?v=oniJoVwlCPY

Direção da Escola de Belas Artes: Roaleno R. A. Costa.

Coordenação da Galeria Cañizares: Edgard Oliva.

Curadoria: José Mário Peixoto.

Registros: Edgard Oliva e Arthur Scovino.

Designer: Bruna Velame.

Artistas e Coletivos:

Andres Murillo (Ex-artista), Ayrson Heráclito (CAHL-UFRB), Carol Érika (PPGACUFBA), Ciane Fernandes e Grupo A-FETO (PPGAC-UFBA), Grupo Mi_Zera (EBAUFBA), Laís Guedes (EBA-UFBA), Maicyra Leão (PPGAC-UFBA), MANDU Performance-Art (CAHL-UFRB), OSSO Coletivo de Performances Urbanas, Rosangela Sousa (EBA-UFBA), Thiago Enoque, Wagner Lacerda (EBA-UFBA), Zmário.

\section{Release:}

O título da Mostra "Corpo Aberto Corpo Fechado" faz alusão às ações e performances apresentadas nos espaços públicos em contraposição às exibições nos espaços institucionais. O Corpo Aberto (vulnerável, instável, imprevisível) na rua, o Corpo Fechado (protegido, adestrado, previsível) na galeria. O objetivo do evento é reunir artistas performáticos e coletivos de performances urbanas em atuação na cidade de Salvador-Bahia e no Recôncavo Baiano para uma série de apresentações e debates sobre a transposição de propostas pensadas para o espaço urbano, as ruas, em direção ao espaço institucional, o museu, a galeria. Como os impedimentos e as regras inerentes à exposição no cubo branco modificam o formato de uma performance ou ação pensada originalmente para o espaço urbano?

José Mário Peixoto.

Programação:

Dia 16.05

Abrindo o Corpo

19h > Grupo Mi_Zera (Arthur Scovino, Gabriel Guerra e Carol Santana EBA-UFBA).

"Qui_zera".

19:30h > Andres Murillo (Ex-artista).

20h > Abertura de portfólio: Maicyra Leão (PPGAC-UFBA).

\section{Dia 17.05}

19h > Laís Guedes (EBA-UFBA). 
19:30h > OSSO Coletivo de Performances Urbanas (Dani Félix, João Matos, Rose Boaretto e Tuti Minervino). "Corpos Ausentes".

20h > Abertura de portfólio: OSSO Coletivo de Performances Urbanas.

\section{Dia 18.05}

19h > Thiago Enoque. "Glutão".

19:30h > Wagner Lacerda e Rosangela Sousa (EBA-UFBA). "Qual é o seu preço?”.

20h > Abertura de portfólio: Grupo Mi_Zera (EBA-UFBA).

\section{Dia 19.05}

19h > Ciane Fernandes e Grupo A-FETO (PPGAC-UFBA)

"GEBO (Runa da Parceria)" obra de Dança-teatro-ritual de/com Ciane Fernandes. "GEBO $\pi$ (Paisagens Internas)" Performance-Oficina de/com o A-FETO Grupo de Dança-Teatro da UFBA: Ana de São José, Ciane Fernandes, Daiane Leal, Felipe Florentino, Frank Haendeler, Lenine Guevara, Morgana Gomes, Sol Tapia. Imagens de Ciane Fernandes, Daniel Sobreira, João Rafael Neto e Uirá Menezes.

19:30h > MANDU Performance-Art (Flávia Pedroso, Julio César, Tiago Sant'Ana e Violeta Martinez CAHL-UFRB). "Proposições para o Recôncavo n ${ }^{\circ}$ 2".

20h > Ayrson Heráclito (CAHL-UFRB). "Batendo Amalá".

20:30h > Abertura de portfólio: MANDU Performance-Art (CAHL-UFRB).

\section{Dia 20.05}

Fechando o Corpo

19h > Bate-Papo de encerramento com a participação de Carol Érika (PPGAC-UFBA) sobre a ação "Na aba do meu chapéu".

20h > Bate-Corpo-Bate-Copo (traga seu instrumento!).

De 16 a 20.05 > Zmário. "Cura dor: tarja pink" (Incorporação \#2).

\section{Referências}

AUSLANDER, Philip. The Performativity of Performance Documentation. Performing Arts Journal, Massachusetts, n. 84, p. 1-10, 2006.

BARROW, John D. The Book of Nothing. Londres: Vintage, 2001.

BASTIDE, Roger; FERNANDES, Florestan. Roger Bastide: sociologia. São Paulo: Ática, 1983.

BERGHAUS, Günter. O Expressionismo no Teatro: interpretação, cenografia e dança. O Percevejo, Rio de Janeiro, UNI-RIO, Ano 5, n. 5, p. 89-96, 1997.

BHABHA, Homi K. O Local da Cultura. Belo horizonte: Editora UFMG, 2005.

BOLSANELlO, Débora Pereira. Em Pleno Corpo: Educação Somática, Movimento e Saúde. Curitiba: Juruá, 2010.

BROWN, Ismene. Marvellous Hybrid Kicks Like a Mule. Londres, 2005. Disponível em: $\quad<$ http://www.telegraph.co.uk/culture/theatre/dance/3645095/Marvellous-hybridkicks-like-a-mule.html>. Acesso em: 12 jul. 2009.

DA COSTA, José. Desconstrução e Retorno do Real. Memória ABRACE X. In: IV CONGRESSO DE PESQUISA E PÓS-GRADUAÇÃO EM ARTES CÊNICAS, 2006, Rio de Janeiro. Anais... Rio de Janeiro: UNIRIO, Viveiros de Castro, 2006. P. 276-277. DESPEUX, Catherine. Tai-Chi Chuan: arte marcial, técnica da longa vida. São Paulo: Pensamento, 1981.

DING, Li. O Qigong Meridiano: transporte de energia pelo meridiano. São Paulo: Ícone, 1996. 
FÉRAL, Josette. O Real na Arte: a estética do choque. 2010. Conferência realizada no VI Congresso da ABRACE, São Paulo, EDUSP, 10 nov. 2010.

FERNANDES, Ciane. Entre Impulso e Estrutura: análise em movimento e videodocumentário no processo criativo em dança-teatro. In: NAVAS, Cássia; ISAACSSON, Marta; FERNANDES, Sílvia (Org.). Ensaios em Cena. São Paulo: Cetera, 2010. P. 82-93.

FERNANDES, Ciane. Paisagens Internas: corpo, performance e meio ambiente. 2010. Trabalho apresentado no VI Congresso da ABRACE, São Paulo: EDUSP, 2010.

FERNANDES, Ciane. Pina Bausch e o Wuppertal Dança-Teatro: repetição e transformação. São Paulo: Hucitec, 2000.

FERNANDES, Ciane. Transmutação Estética: a criação cênica a partir do sistema Laban/Bartenieff, do movimento genuíno e da vivência somática. 2010. Palestra realizada no $2^{\circ}$ Seminário Internacional de Educação Estética: entrelugares do corpo e da arte, UNICAMP, 26 ago. 2010.

FOSTER, Hal. The Return of the Real. Cambridge, Massachusetts: The MIT Press, 1996.

GOLDBERG, RoseLee. Performance Art from Futurism to the Present. New York: Harry N. Abrams, 1988.

GORDON, Mel (Org.). Dada Performance. New York: PAJ Publications, 1987.

JODELET, Denise. Diversidade e Alteridade. 2009. Conferência realizada no IX Encontro Nacional de Ensino e Pesquisa em Informação (CINFORM), Salvador, junho de 2009.

KOURLAS, Gia. Humiliation and Death on a Fatefull Jorney. New York: 2008. Disponível em: <http://www.nytimes.com/2008/04/28/arts/dance/28khan.html>. Acesso em: 12 jul. 2009.

KUNIFAS, Cinthia. Corpo Desconhecido: um contínuo processo de criação em dança. Dissertação (Mestrado em Artes Cênicas) - Programa de Pós-Graduação em Artes Cênicas, Universidade Federal da Bahia, Salvador, 2008.

LABAN, Rudolf. A Vision of Dynamic Space. Londres: Laban Archives \& The Falmer Press, 1984.

LEPECKI, André. Desfazendo a Fantasia do Sujeito (dançante): "Still acts" em The Last Performance de Jérome Bel. Lições de Dança, Rio de Janeiro, UniverCidade, n. 5, p. 11-26, 2005.

LEPECKI, André. Of The Presence of The Body: essays on dance and performance theory. Middletown, Connecticut: Wesleyan University Press, 2004.

LEPECKI, André. Stress. In: BRANDSTETTER, Gabriele Brandstetter; VÖLCKERS, Hortensia (Org.). ReMembering the Body. Ostfildern-Ruit: Hatje Cantz Verlag, 2000.

LEVINE, Peter. O Despertar do Tigre: curando o trauma. São Paulo: Summus, 1993.

MAHABHARATA, Bhagavad Gita. Bhagavad Gita: canção do divino mestre. Tradução do sânscrito, introdução e notas de Rogério Duarte. São Paulo: Companhia das Letras, 1998.

MELZER, Annabelle H. Dada and Surrealist Performance. Baltimore: Johns Hopkins University, 1994.

NAGAMOTO, Shigenori. Attunement Through the Body. New York: State University of New York, 1992.

NISHINO, Koso. The Breath of Life. Japan: Kodansha International, 1997.

Ciane Ferandes, Pausa, Presença, Público: da Dança-Teatro à Performance-Oficina

R.bras.est.pres., Porto Alegre, v.1, n.1, p. 77-106, jan./jun., 2011.

Disponível em http://www.seer.ufrgs.br/presenca 
PAIVA, Luciana. A Fragilidade como Potência: precariedade e imagem. VIS, Brasília, Programa de Pós-Graduação em Artes da Universidade de Brasília, v. 9, n. 1, p. 69-75, jan./jun. 2010.

PEIXOTO, José Mário. Release da Mostra CorpoAbertoCorpoFechado. Salvador: Galeria Cañizares, 2011.

QUILICI, Cassiano S. O "Contemporâneo" e as Experiências do Tempo. In: NAVAS, Cássia; ISAACSSON, Marta; FERNANDES, Sílvia (Org.). Ensaios em Cena. São Paulo: Cetera, 2010. P. 24-33.

SIEBENS, Tobin (Org.). The Body Aesthetic: from fine art to body modification. Ann Arbor: University of Michigan Press, 2000.

SOLOMON, Ruth; SOLOMON, John. What is Dance? An interview with Park Myungsook. East Meets West in Dance: voices in the cross-cultural dialogue. Amsterdam: Harwood Academic Publishers, 1997. P. 233-237.

WARR, Tracey; JONES, Amelia. The Artist's Body. Londres: Phaidon, 2000. WATTS, Graham. Akram Khan and Sidi Larbi Cherkaoui 'Zero Degrees'. Londres: 2005.

Disponível

em: <http://www.ballet.co.uk/magazines/yr_05/aug05/gw_rev_akram_khan_and_sidi_larbi_ cherkaoui_0705.htm>.Acesso em: 12 jul. 2009.

WHITEHOUSE, Mary S. Reflections on a Metamorphosis. In: PALLARO, Patricia (Org.). Authentic Movement: essays by Mary Starks Whitehouse, Janet Adler and Joan Chodorow. Londres: Jessica Kingsley Publishers, 2000.

Ciane Fernandes é performer e coreógrafa, professora da Escola de Teatro e do Programa de Pós-Graduação em Artes Cênicas da Universidade Federal da Bahia, mestre e Ph.D. em Artes \& Humanidades para Intérpretes das Artes Cênicas pela New York University, pós-doutora em Comunicação e Cultura Contemporâneas pela Faculdade de Comunicação da UFBA, e Analista de Movimento pelo Laban/Bartenieff Institute of Movement Studies, New York, do qual é pesquisadora associada.

E-mail: cianef@gmail.com 